\title{
Performance of lambs fed alternative protein sources to soybean meal
}

\author{
Felipe José Lins Alves ${ }^{1}$, Marcelo de Andrade Ferreira ${ }^{1}$, Stela Antas Urbano ${ }^{2}$, Rafael de Paula \\ Xavier de Andrade ${ }^{3}$, Ághata Elins Moreira da Silva', Michelle Christina Bernardo de Siqueira ${ }^{1}$, \\ Juliana Paula Felipe de Oliveira ${ }^{1}$, Janaina de Lima Silva ${ }^{1}$
}

\footnotetext{
${ }^{1}$ Universidade Federal Rural de Pernambuco, Departamento de Zootecnia, Recife, PE, Brazil.

2 Universidade Federal do Rio Grande do Norte, Departamento de Agropecuária, Natal, RN, Brazil.

${ }^{3}$ Universidade Federal do Sul e Sudeste do Pará, Instituto de Estudos do Trópico Úmido, Xinguara, PA, Brazil.
}

\begin{abstract}
The objective of this study was to evaluate the effect of alternative protein sources (castor bean cake, sunflower cake, and sunflower seed) to soybean meal on the intake and performance of 40 lambs, initially weighing $19.8 \pm 1.84 \mathrm{~kg}$, fed diets based on Tifton grass hay. The experimental design was completely randomized blocks. There were no differences in the nutrient intake of castor bean diets compared with soybean meal. The intake of nutrients in the sunflower cake and sunflower seed diets was decreased compared with soybean meal. The apparent digestibility coefficients of dry matter, organic matter, crude protein, and neutral detergent fiber of sunflower cake and sunflower seed diets were decreased compared with soybean meal. The average daily weight gain of animals fed the castor bean diet $(0.190 \mathrm{~kg}) \mathrm{was}$ not different from that of the animals fed the soybean meal diet $(0.217 \mathrm{~kg})$. The sunflower cake and sunflower seed diets provided less weight gain ( 0.171 and $0.135 \mathrm{~kg} \mathrm{~d}^{-1}$, respectively) than soybean meal due to the lower nutrient intake. The hot carcass yield and true yield were not affected by the protein sources. The neck, ribs, and ham weights were similar in lambs fed soybean meal and castor bean cake diets. It is recommended to use castor bean as an alternative protein source in the diet of lambs.
\end{abstract}

Key Words: biofuels byproducts, carcass quality, feed evaluation, intake, protein supplementation

\section{Introduction}

Soybean meal is the main protein source in animal feed. However, the high price of transporting from regions of soybean production, the increase in the world population, and the growing demand for protein-rich foods that do not compete with human food sources have encouraged the search for alternative feeds to replace soybean meal in animal diets (Haddad, 2006).

The search for renewable alternatives to the use of oil biofuels, prominently in the global economy, is an ecologically correct option for environmental preservation. Also, by launching the National Program for Production and Use of Biodiesel through Law No. 11,097 of January 13, 2005, the Brazilian government increased the share of biofuels in the Brazilian energy matrix (Brasil, 2005). Among the most prominent oil-producing plants for regional production of biodiesel are castor bean and sunflower plants.

Received August 7, 2015 and accepted October 26, 2015. Corresponding author: silva_janainalima@yahoo.com.br

http://dx.doi.org/10.1590/S1806-92902016000400001

Copyright (C) 2016 Sociedade Brasileira de Zootecnia. This is an Open Access article distributed under the terms of the Creative Commons Attribution License (http://creativecommons.org/licenses/by/4.0/), which permits unrestricted use, distribution, and reproduction in any medium, provided the original work is properly cited.
The castor bean (Ricinus communis L.) is considered the most important oilseed crop for biodiesel production, especially in Northeast Brazil, because it has an extensive range of adaptation, easy management, drought tolerance, and low production costs. One of the products of castor bean production, the castor bean cake, has been used predominantly as a quality organic fertilizer because it is rich in nitrogen and efficient at recovering depleted lands. However, it can obtain a significantly higher value if used as food because of its high protein content (Diniz et al., 2011).

The sunflower (Helianthus annuus), in both seed and cake forms, has become an alternative feed for ruminants due to its high levels of protein and energy, and the effects of the addition of sunflower products to the diets of ruminants have been studied by several researchers (Mendoza et al., 2008). According to Oliveira et al. (2007), the sunflower cake can be considered a protein concentrate food $(>20 \%$ crude protein) with high ruminal degradability of protein $(>90 \%)$.

Sunflower oil extraction can be performed using chemical solvents (resulting in bran) or press (resulting in cakes). The cakes contain high levels of fat due to inefficiencies in the extraction process and result in approximately $20 \%$ fat and just over $26 \%$ crude protein (Moura et al., 2015). 
Therefore, the aim of this study was to evaluate different protein sources alternative to soybean meal in lamb diets and their effects on nutrient intake, digestibility, and performance.

\section{Material and Methods}

The experiment was conducted in the municipality of Recife, Pernambuco, Brazil. The management and care of animals were performed by the guidelines and recommendations of the Institutional Committee on Animal Care and Use (No. 003/2012), wherein this experiment was part of the project "Use of biodiesel co-products in sheep feeding".

Forty male lambs (non-defined breed standard, with the strong breed characterization of Santa Ines breed) were used in a feedlot with an average initial body weight of $19.8 \pm 1.84$ $\mathrm{kg}$ and five months of age. The experimental design was complete randomized blocks with four treatments and ten replicates, and the animals' initial weight was the criterion for block formation. The experiment lasted 100 days, of which 30 days were used for adaptation to the diets and installations and 70 days for data and sample collection.

The treatments consisted of different protein sources: soybean meal (SBM), castor bean cake (CB), sunflower cake (SC), and sunflower seeds (SS) (Tables 1 and 2). The $\mathrm{CB}$ was acquired from Biodiesel Plant Governor Miguel Arraes, in the municipality of Pesqueira, PE, Brazil; this by-product was detoxified by autoclaving at 15 psi for 60 min according to the methodology of Anandan et al. (2005). The BRS 321 cultivars of SS and SBM were acquired from a local market, and the SS was ground in a fodder machine. The SC was acquired from Petrobras plant, in the municipality of Ceará Mirim, RN, Brazil, obtained after the mechanical pressing procedure.

Table 1 - Chemical composition of ingredients on a dry matter basis

\begin{tabular}{lccccccc}
\hline Ingredient & $\mathrm{DM}^{1}$ & $\mathrm{OM}^{2}$ & $\mathrm{CP}^{2}$ & $\mathrm{EE}^{2}$ & $\mathrm{NDF}^{2}$ & $\mathrm{ADF}^{2}$ & Lignin $^{2}$ \\
\hline Tifton hay & 894 & 931 & 95.7 & 19.6 & 735 & 328 & 41.3 \\
Ground corn & 885 & 983 & 86.0 & 59.5 & 133 & 31.6 & 9.90 \\
Soybean meal & 898 & 938 & 454 & 19.4 & 141 & 65.9 & 9.00 \\
Castor bean cake & 929 & 942 & 285 & 103 & 565 & 403 & 293 \\
Sunflower cake & 920 & 959 & 254 & 120 & 456 & 250 & 63.9 \\
Sunflower seed & 920 & 976 & 245 & 398 & 701 & 447 & 112 \\
Mineral salt & 990 & 10 & 0 & 0 & 0 & 0 & 0 \\
Urea + ammonium & 990 & 10 & 2600 & 0 & 0 & 0 & 0
\end{tabular}

sulfate

DM - dry matter; OM - organic matter; CP - crude protein; EE - ether extract; NDF neutral detergent fiber; ADF - acid detergent fiber.

${ }^{1} \mathrm{~g} \mathrm{~kg}^{-1}$ as fed.

$2 \mathrm{~g} \mathrm{~kg}^{-1}$ dry matter.

3 Nutrients/kg of product: calcium - $173 \mathrm{~g}$; phosphorus - $30 \mathrm{~g}$; sodium - $148 \mathrm{~g}$; magnesium - $70 \mathrm{~g}$, iron - 2,200 mg; cobalt - $140 \mathrm{mg}$; manganese - 3,690 mg; zinc 4,700 mg; iodine - $61 \mathrm{mg}$; selenium - $45 \mathrm{mg}$; sulfur - $12 \mathrm{~g}$; fluorine - $700 \mathrm{mg}$.
The soybean meal diet was formulated to meet the nutritional requirements of animals with $25 \mathrm{~kg}$ and an average daily gain of $200 \mathrm{~g}$ (NRC, 2007). Diets were offered as a total mixed ration, ad libitum, twice daily, in two equal meals at $07.00 \mathrm{~h}$ and $16.00 \mathrm{~h}$, allowing $10 \%$ of orts. The orts were sampled, placed in labeled bags, and stored in the freezer for later analysis. The ingredients of the diets were sampled weekly, totaling ten samples per animal over a 100-day trial period.

After a 50-day experimental period, fecal dry matter output was estimated using LIPE ${ }^{\circledR}$ (modified and enriched hydroxyphenyl propane - purified lignin from eucalyptus) as an external marker to calculate total tract apparent digestibility of the feed nutrients (Lima et al., 2008). The marker was administered in the form of capsules $(250 \mathrm{mg} /$ animal) over seven days (two days for adaptation followed by five days for data collection) in the morning, at $07.00 \mathrm{~h}$ (single dose). The fecal samples were collected rectally, manually, using disposable gloves, once a day, from each animal, on the 1st, 2nd, 3rd, 4th and 5th days of the collection period, at $06.00,8.00,10.00,12.00$, and $14.00 \mathrm{~h}$, respectively. The samples were oven-dried at $65^{\circ} \mathrm{C}$ for $72 \mathrm{~h}$ and ground using a Wiley mill with a $1 \mathrm{~mm}$ screen. After drying, the samples were mixed to obtain one value for dry matter. The fecal samples were analyzed according to the methodology of Saliba et al. (2003).

Dry matter $(\mathrm{DM})$, organic matter $(\mathrm{OM})$, and crude protein (CP) analyses were performed according to the

Table 2 - Proportion of ingredients and chemical composition of experimental diets

\begin{tabular}{|c|c|c|c|c|}
\hline \multirow{2}{*}{ Ingredient $^{1}$} & \multicolumn{4}{|c|}{ Protein source } \\
\hline & SBM & $\mathrm{CB}$ & $\mathrm{SC}$ & SS \\
\hline Tifton hay & 500 & 500 & 500 & 500 \\
\hline Ground corn & 362 & 354 & 352 & 352 \\
\hline Soybean meal & 120 & 0 & 0 & 0 \\
\hline Castor bean cake & 0 & 120 & 0 & 0 \\
\hline Sunflower cake & 0 & 0 & 120 & 0 \\
\hline Sunflower seed & 0 & 0 & 0 & 120 \\
\hline Mineral salt & 15 & 15 & 15 & 15 \\
\hline Urea + ammonium sulfate ${ }^{2}$ & 3 & 11 & 13 & 13 \\
\hline \multicolumn{5}{|l|}{ Chemical composition } \\
\hline Dry matter ${ }^{3}$ & 893 & 897 & 896 & 896 \\
\hline Organic matter ${ }^{1}$ & 934 & 926 & 927 & 929 \\
\hline Crude protein ${ }^{1}$ & 142 & 142 & 142 & 142 \\
\hline Ether extract ${ }^{1}$ & 34 & 43 & 45 & 79 \\
\hline Neutral detergent fiber ${ }^{1}$ & 433 & 482 & 469 & 498 \\
\hline Acid detergent fiber ${ }^{1}$ & 184 & 224 & 205 & 229 \\
\hline Non-fiber carbohydrates ${ }^{1}$ & 325 & 259 & 271 & 210 \\
\hline Lignin $^{1}$ & 25 & 59 & 32 & 38 \\
\hline Metabolizable energy (Mcal kg-1 DM) & 2.62 & 2.73 & 2.51 & 2.11 \\
\hline \multicolumn{5}{|c|}{$\begin{array}{l}\text { SBM - soybean meal; CB - castor bean cake; } \mathrm{SC} \text { - sunflower cake; SS - sunflowe } \\
\text { seed. } \\
{ }^{1} \mathrm{~g} \mathrm{~kg}^{-1} \text { dry matter. } \\
29 \text { parts of urea to } 1 \text { part of ammonium sulfate mixed with the concentrate of diet. }^{3} \mathrm{~g} \mathrm{~kg}^{-1} \text { as fed. }\end{array}$} \\
\hline
\end{tabular}


AOAC (1990), method number 934.01 for DM, 930.05 for $\mathrm{OM}$, and 981.10 for CP. Ether extract (EE) was analyzed by Soxhlet extraction with petroleum ether, according to the AOAC (1990), method number 920.39. The concentration of neutral detergent fiber was assayed with heat-stable amylase and corrected for ash based on the procedures described by Mertens (2002), except that the samples were placed in polyethylene bottles with $100 \mathrm{~mL}$ of neutral detergent and autoclaved (Senger et al., 2008). For determination of acid detergent fiber (ADF), $100 \mathrm{~mL}$ of acid detergent were added (Van Soest and Robertson, 1985). Neutral detergent insoluble nitrogen (NDIN) and acid detergent insoluble nitrogen (ADIN) (Licitra et al., 1996) were measured using the Kjeldahl method. Non-fiber carbohydrates (NFC) were calculated according to Hall (2000), as follows:

$\mathrm{NFC}\left(\mathrm{g} \mathrm{kg}^{-1}\right)=1000-[(\mathrm{CP}-$ urea derived $\mathrm{CP}+$ urea $)+$ $\mathrm{NDFap}+\mathrm{EE}+\mathrm{ash}]$,

in which $\mathrm{CP}=$ crude protein; NDFap $=$ neutral detergent fiber corrected for ash and protein; and $\mathrm{EE}=$ ether extract.

The direct method was used for the determination of apparent digestibility of the nutrients, by evaluating the levels of nutrients in feed and feces samples. Total digestible nutrients (TDN) were calculated using the equation proposed by Weiss (1999):

$\mathrm{TDN}(\%)=\mathrm{CPD}+\mathrm{NDFD}+\mathrm{NFCD}+2.25 \times \mathrm{EED}$, in which $\mathrm{CPD}=$ digestible crude protein; $\mathrm{NDFD}=$ digestible neutral detergent fiber; and EED = digestible ether extract. The TDN concentration was calculated as follows:

$\mathrm{TDN}(\%)=\mathrm{TDN}$ Intake/DM intake,

which can be converted to metabolizable energy (Harris, 1970) using the following equation:

ME $\left(\right.$ Mcal kg $\left.{ }^{-1} \mathrm{DM}\right)=(\mathrm{kg} \mathrm{TDN} \times 4.409$ Mcal DE $) \times 0.82$.

After $70 \mathrm{~d}$ on their respective experimental feeds (not including adaptation period), animals were subjected to a water diet and solid fasting for $16 \mathrm{~h}$. Immediately before slaughter, they were weighed to obtain "body weight at slaughter" (BWS). At slaughter, the animals were stunned by concussion, followed by bleeding out through a section of the carotid artery and jugular vein. After skinning and evisceration, the head (sectioned at the atlanto-occipital joint) and the feet (sectioned at the metacarpal and metatarsal joints) were removed, and hot carcass weight (HCW) was recorded. The gastrointestinal tract was weighed full and empty to determine the empty body weight (EBW) and biological yield $[\mathrm{BY}(\%)=\mathrm{HCW} / \mathrm{EBW} \times 100]$.

The carcasses were chilled for $24 \mathrm{~h}$ in a $4{ }^{\circ} \mathrm{C}$ cold room and hung using hooks, with the metatarsal joints spaced by $17 \mathrm{~cm}$. After cooling, the carcasses were weighed, deducting the weight of the kidney and perirenal fat, to obtain the cold carcass weight $(\mathrm{CCW})$. The hot carcass yield was calculated as $[\mathrm{HCY}(\%)=\mathrm{HCW} / \mathrm{BWS} \times 100]$, and the commercial yield was calculated as $[\mathrm{CY}(\%)=\mathrm{CCW} / \mathrm{BWS} \times 100]$.

The carcasses were cut in half, and each half-carcass was weighed. The left half was sectioned into seven anatomic regions, using the methods adapted from Cezar and Souza (2007) originating the commercial cuts neck, loin, shoulder (section obtained by disarticulation of the scapula, humerus, radius, ulna, and carpus), ham (section between the last lumbar and 1st sacral vertebrae), ribs (section between the 1st and 6th lumbar vertebrae), and pistola (section obtained by straight cutting from the flank to the cranial end of the sternum manubrium).

The variables analysis was performed using the PROC MIXED procedures of SAS statistical package (Statistical Analysis System, version 9.1), according to the following model:

$$
\mathrm{Y}_{\mathrm{ij}}=\mu+\mathrm{T}_{\mathrm{i}}+\beta\left(\mathrm{X}_{\mathrm{ij}}-\mathrm{X}\right)+\mathrm{e}_{\mathrm{ij}},
$$

in which $\mu$ is the overall constant; $T_{i}$ is the effect of treatment $\mathrm{i}(\mathrm{i}=1$ to 4$) ; \beta\left(\mathrm{X}_{\mathrm{ij}}-\mathrm{X}\right)$ is the covariate effect (initial weight); and $\mathrm{e}_{\mathrm{ij}}$ is the random unobservable error. Data were subjected to analysis of variance and the means were compared using Dunnett's test, considering the soybean meal diet as control.

\section{Results}

The intakes of DM, OM, CP, NDF, and ME in lambs fed castor bean cake did not differ $(\mathrm{P}>0.05)$ from animals fed soybean meal (Table 3 ). The DM intake of diets containing sunflower cakes $\left(0.857 \mathrm{~kg} \mathrm{~d}^{-1}\right)$ or sunflower seeds $\left(0.789 \mathrm{~kg} \mathrm{~d}^{-1}\right)$ were lower compared with the soybean meal $\left(0.989 \mathrm{~kg} \mathrm{~d}^{-1}\right)$. Similarly, the lambs fed sunflower cake and sunflower seed had a lower intake $(\mathrm{P}<0.001)$ of $\mathrm{OM}$, $\mathrm{CP}$, and ME compared with those fed soybean meal. The EE intake was lower $\left(0.040 \mathrm{~kg} \mathrm{~d}^{-1}\right)$ in the animals fed soybean meal than in those on the other treatments $(\mathrm{P}<0.001)$. Neutral detergent fiber intake was similar $(\mathrm{P}>0.05)$ between lambs fed soybean meal $\left(0.409 \mathrm{~kg} \mathrm{~d}^{-1}\right)$, castor bean cake $\left(0.447 \mathrm{~kg} \mathrm{~d}^{-1}\right)$, and sunflower cake $\left(0.391 \mathrm{~kg} \mathrm{~d}^{-1}\right)$, and higher $(\mathrm{P}<0.001)$ than in those lambs fed sunflower seed $\left(0.352 \mathrm{~kg} \mathrm{~d}^{-1}\right)$. Lower digestibility $(\mathrm{P}<0.001)$ of $\mathrm{DM}$, OM, $\mathrm{CP}$, and NDF was observed in lambs fed sunflower seed than in those fed soybean meal (Table 3). The castor bean cake diet showed similar $(\mathrm{P}>0.05)$ digestibility of $\mathrm{DM}$, $\mathrm{OM}$, and $\mathrm{CP}$ to the soybean meal. However, the sunflower cake showed less $(\mathrm{P}<0.001)$ digestibility of $\mathrm{DM}$ and $\mathrm{OM}$ compared with soybean meal.

Body weight at slaughter (BWS), empty body weight (EBW), hot carcass weight ( $\mathrm{HCW}$ ), and cold carcass weight $(\mathrm{CCW})$ were higher $(\mathrm{P}<0.001)$ in the animals fed soybean 
meal compared with the animals fed other protein sources (Table 4). The total weight gain and the average daily gain $(\mathrm{ADG})$ were similar $(\mathrm{P}>0.05)$ for animals fed the castor bean cake compared with the animals fed the soybean meal (Table 4).

The hot carcass yield (HCY) and true yield (TY) were not affected by the protein sources $(\mathrm{P}>0.05)$ (Table 4).
Higher weights $(\mathrm{P}<0.01)$ of the shoulder, pistola, and loin were observed in animals fed soybean meal diet compared with those consuming the other diets (Table 5). The neck, ribs, and ham weights were similar $(\mathrm{P}>0.05)$ in lambs fed soybean meal and castor bean cake diets (Table 5). The ribs of the sheep fed sunflower had a lower weight $(\mathrm{P}<0.01)$ compared with the other treatments.

Table 3 - Intake and digestibility of nutrients of lambs fed alternative protein sources to soybean meal

\begin{tabular}{|c|c|c|c|c|c|c|}
\hline \multirow{2}{*}{ Item } & \multicolumn{4}{|c|}{ Protein source } & \multirow{2}{*}{ SEM } & \multirow{2}{*}{ P-value } \\
\hline & SBM & $\mathrm{CB}$ & $\mathrm{SC}$ & SS & & \\
\hline \multicolumn{7}{|l|}{ Intake $\left(\mathrm{kg} \mathrm{d}^{-1}\right)$} \\
\hline Dry matter & 0.989 & 0.964 & 0.857 & $0.789 \diamond$ & 0.002 & $* * *$ \\
\hline Organic matter & 0.919 & 0.889 & $0.791 \bullet$ & 0.733 & 0.001 & $* * *$ \\
\hline Crude protein & 0.146 & 0.140 & 0.125 & 0.108 & 0.001 & $* * *$ \\
\hline Ether extract & 0.040 & 0.050 & 0.046 & 0.069 & 0.0001 & $* * *$ \\
\hline Neutral detergent fiber & 0.409 & 0.447 & 0.391 & 0.352 & 0.003 & $* * *$ \\
\hline Metabolizable energy (Mcal kg-1 DM) & 2.59 & 2.63 & 2.15 & 1.66 & 0.022 & $* * *$ \\
\hline \multicolumn{7}{|l|}{ Digestibility $\left(\mathrm{g} \mathrm{kg}^{-1}\right)$} \\
\hline Dry matter & 690 & 700 & 630 & 510 & 0.003 & $* * *$ \\
\hline Organic matter & 700 & 710 & 640 & 520 & 0.002 & $* * *$ \\
\hline Crude protein & 640 & 690 & 620 & 490 & 0.001 & $* * *$ \\
\hline Neutral detergent fiber & 510 & $610 \bullet$ & 490 & $350 \bullet$ & 0.002 & $* * *$ \\
\hline
\end{tabular}

SBM - soybean meal; CB - castor bean cake; SC - sunflower cake; SS - sunflower seed; SEM - standard error of the mean.

-Values differ statistically from the control treatment - Dunnett's test.

Significance levels: $* * * \mathrm{P}<0.001$.

Table 4 - Performance and carcass traits of lambs fed alternative protein sources to soybean meal

\begin{tabular}{|c|c|c|c|c|c|c|}
\hline \multirow{2}{*}{ Item } & \multicolumn{4}{|c|}{ Protein source } & \multirow{2}{*}{ SEM } & \multirow{2}{*}{ P-value } \\
\hline & SBM & $\mathrm{CB}$ & $\mathrm{SC}$ & SS & & \\
\hline IBW (kg) & 19.9 & 19.0 & 19.8 & 19.8 & 0.175 & ns \\
\hline BWS (kg) & 34.7 & 31.9 & 31.5 & 29.6 & 0.893 & $* * *$ \\
\hline $\mathrm{TG}(\mathrm{kg})$ & 14.8 & 12.9 & 11.6 & 9.18 & 0.698 & $* * *$ \\
\hline $\operatorname{ADG}\left(\mathrm{kg} \mathrm{d}^{-1}\right)$ & 0.217 & 0.190 & 0.171 & 0.135 & 0.0001 & $* * *$ \\
\hline HCW (kg) & 15.9 & 14.2 & 14.1 & 12.6 & 0.242 & $* * *$ \\
\hline $\mathrm{HCY}(\%)$ & 46.15 & 44.45 & 44.83 & 43.15 & 0.880 & ns \\
\hline CY (\%) & 44.24 & 42.51 & 42.99 & 40.86 & 0.680 & $* *$ \\
\hline
\end{tabular}

SBM - soybean meal; CB - castor bean cake; SC - sunflower cake; SS - sunflower seed; SEM - standard error of the mean; IBW - initial body weight; BWS - body weight at slaughter; EBW - empty body weight; TG - total gain; ADG - average daily gain; HCW - hot carcass weight; CCW - cold carcass weight; BY - biological yield; HCY - hot carcass yield; CY - commercial yield.

-Values differ statistically from the control treatment - Dunnett's test.

Significance levels: $* \mathrm{P}<0.05, * * \mathrm{P}<0.01, * * * \mathrm{P}<0.001$, ns - not significant.

Table 5 - Commercial cuts of lambs fed alternative protein sources to soybean meal

\begin{tabular}{|c|c|c|c|c|c|c|}
\hline \multirow{2}{*}{ Item } & \multicolumn{4}{|c|}{ Protein source } & \multirow{2}{*}{ SEM } & \multirow{2}{*}{ P-value } \\
\hline & SBM & $\mathrm{CB}$ & $\mathrm{SC}$ & $\mathrm{SS}$ & & \\
\hline Neck (kg) & 0.79 & 0.72 & $0.67 \diamond$ & $0.67 \diamond$ & 0.001 & $*$ \\
\hline Shoulder (kg) & 1.43 & 1.27 & 1.24 & 1.14 & 0.002 & $* * *$ \\
\hline Ribs (kg) & 1.21 & 1.11 & 1.09 & 0.98 & 0.003 & $* *$ \\
\hline Pistola (kg) & 0.92 & 0.80 & 0.79 & 0.67 & 0.001 & $* * *$ \\
\hline Loin $(\mathrm{kg})$ & 0.75 & 0.64 & 0.65 & 0.59 & 0.001 & $* *$ \\
\hline Ham (kg) & 2.25 & 2.06 & 2.00 & 1.86 & 0.008 & $* *$ \\
\hline
\end{tabular}

SBM - soybean meal; CB - castor bean cake; SC - sunflower cake; SS - sunflower seed; SEM - standard error of the mean.

$\checkmark$ Values differ statistically from the control treatment - Dunnett's test.

Significance levels: $* \mathrm{P}<0.05$, $* * \mathrm{P}<0.01, * * * \mathrm{P}<0.001$. 


\section{Discussion}

Despite the greater lignin content in castor bean cake compared with soybean meal, which, according to Van Soest (1994), reduces the rate of ruminal fiber degradation and increases the retention time, thereby reducing intake, there was no difference in the intakes of DM and nutrients between the castor bean cake and soybean meal. The lack of effect, according to Oliveira et al. (2010) is due to the small particle size, which facilitates the passage rate of the indigestible fraction.

The lower DM intake in lambs fed sunflower cake or sunflower seed compared with the soybean meal could be explained by the greater EE content above $70 \mathrm{~g} \mathrm{~kg}^{-1}$ in the sunflower diets (Table 1). According to Van Soest (1994), higher EE contents lead to decreased fiber digestion due to the intoxication of fibrolytic rumen microorganisms, increasing the feed retention time in the rumen and decreasing feed intake. Although the EE contains more energy, the higher intake of this nutrient was not sufficient to compensate for the decrease in DM intake in lambs fed sunflower seed and sunflower cake, resulting in the lowest weight gain.

The CP intake decreased by $14.5 \%$ and $25.7 \%$ in lambs fed the sunflower cake and sunflower seed, respectively, compared with the diet with soybean meal. These results were influenced by the lower DM intake of these diets, which also explains the decreased intake of organic matter in these diets compared with the soybean meal diet.

Except for NDF, the nutrient digestibility of the castor bean cake diet did not differ from the control diet. Due to the greater content of lignin in the castor bean cake (Table 1), an effect was expected on the digestibility of DM and nutrients. According to Van Soest (1994), the lignin fraction exerts a greater effect on digestibility than on intake. However, the lignin cross-linking of cell wall polysaccharides (notably hemicellulose) and ferulic acid are prerequisites for the occurrence of this effect (Jung and Allen, 1995). Probably, the small particle size combined with the effect of cooking the castor bean cake on the lignin arrangement (less resistant to digestion) allows the accessibility of rumen microorganisms to the potentially digestible fraction of nutrients. Similarly, Oliveira et al. (2010) did not find intake differences comparing castor seed meal (CSM) and soybean meal, and suggested that the rapid degradation rate of the NDF fraction potentially degradable in the rumen and the small particle size of CSM increased the ruminal disappearance of NDF from CSM.
The lower digestibility of DM and nutrients in the sunflower seed and sunflower cake (except CP and NDF) diets compared with the soybean meal diet was probably related to the EE and ADF contents of the diets. The greater EE content in the sunflower seed diet, which exceeded the critical limit (5\% EE in the diet), adversely affects nutrient intake. According to Palmquist and Mattos (2006), this effect is caused either by the limited capacity of ruminants to oxidize fatty acids or even the physical effect of the covering of feed particles with fat, impairing the digestion agents. According to Van Soest (1994), the ADF content is closely related to feed digestibility, which is due to the presence of lignin, which in turn involves food particles, preventing the attack of microorganisms.

The similar total gain and average daily gain (ADG) between lambs fed the castor bean cake and soybean meal was directly related to same DM intake and intakes of $\mathrm{CP}$ and ME. Only the diets containing soybean meal and castor bean cake met the requirements for an average weight gain of $0.200 \mathrm{~g} \mathrm{~d}^{-1}$ in this animal category. For this ADG, the NRC (2007) recommended a DM intake of $0.860 \mathrm{~kg} \mathrm{~d}^{-1}$, thus justifying the result.

The lambs fed sunflower cake and sunflower seed presented lower total and daily weight gains than lambs fed soybean meal, explained by decrease in DM intake, CP, and ME. Thus, the better carcass weight of lambs fed the soybean meal diet was related to the average daily gain of $0.217 \mathrm{~kg} \mathrm{~d}^{-1}$, which resulted in a higher slaughter weight and carcass weight, reflecting in the cold carcass weight of $15.3 \mathrm{~kg}$. The carcass weights of sheep fed alternative protein sources were lower than the $15 \mathrm{~kg}$ proposed by Zapata et al. (2001) for lamb carcasses. Nevertheless, the hot carcass yield and biological yield were not affected by the alternative protein sources.

The higher weight of cuts was directly related to the animal's carcass weight, which was higher in animals fed soybean meal. However, because of the similarity of the neck, ribs, and ham weights of lambs fed soybean meal and castor bean cake $(\mathrm{CB})$, we can infer that $\mathrm{CB}$ represents a good alternative protein source for finishing lambs. The ham was the heaviest cut, which is important, since it is a region with greater muscularity and higher yield of edible portions (Silva Sobrinho et al., 2005). The lower cuts' weights in lambs fed sunflower cake (except ribs) and sunflower seed can be attributed to the decrease in DM, CP, and ME intakes. According to Piola Junior et al. (2009), the deficit in energy intake results in reduced yield of carcass and its cuts. 


\section{Conclusions}

It is recommended to use castor bean cake detoxified by autoclaving at $15 \mathrm{psi}$ for $60 \mathrm{~min}$ as an alternative protein source to soybean meal in diets for feedlot finishing lambs.

\section{Acknowledgments}

This work was supported by Conselho Nacional de Desenvolvimento Científico e Tecnológico - CNPq.

\section{References}

Anandan, S.; Kumar, A. G. K; Ghosh, J. and Ramachandra, K. S. 2005. Effect of different physical and chemical treatments on detoxification of ricin in castor cake. Animal Feed Science and Technology 120:159-168.

AOAC - Association of Official Analytical Chemists. 1990. Official methods of analysis. 15th ed. AOAC International, Arlington, VA.

Brasil. 2005. Ministério da Agricultura, Pecuária e do Abastecimento (MAPA). Secretaria da Defesa Agropecuária (SDA). Departamento de Inspeção de Produtos de Origem Animal (DIPOA). Divisão de Normas Técnicas. Instrução Normativa n. 3, de 17 de janeiro de 2000. Lex: Diário Oficial da União de 24 de janeiro de 2000, Seção 1:14-16.

Cezar, M. F. and Souza, W. H. 2007. Carcaças ovinas e caprinas: obtenção, avaliação e tipificação. UFCG, Campina Grande, PB.

Diniz, L. L.; Valadares Filho, S. C.; Oliveira, A. S.; Pina, D. S.; Silva, L. D.; Benedeti, P. B.; Baião, G. F.; Campos, J. M. S. and Valadares, R. F. D. 2011. Castor bean meal for cattle finishing: 1-Nutritional parameters. Livestock Science 2:153-167.

Haddad, S. G. 2006. Bitter vetch grains as a substitute for soybean meal for growing lambs. Livestock Science 2:221-225.

Hall, M. B. 2000. Calculation of non-structural carbohydrate content of feeds that contain non-protein nitrogen. University of Florida, Gainesville. p.A-25 (Bulletin 339).

Harris, L. F. 1970. Nutrition research technique for domestic and wild animal. 1st ed. Logan, Utah.

Jung, H. G. and Allen, S. 1995. Characteristics of plant cell walls affecting intake and digestibility of forages by ruminants. Journal of Animal Science 73:2774-2790.

Licitra, G.; Hernandez, T. M. and Van Soest, P. J. 1996. Standardization of procedures for nitrogen fractionation of ruminant feeds. Animal Feed Science and Technology 57:347-358.

Lima, J. B. M. P.; Graça, D. S.; Borges, A. L. C. C.; Saliba, E. O. S. and Simão, S. M. B. 2008. Uso do óxido crômico e do LIPE $^{\circledR}$ na estimativa do consumo de matéria seca por bezerros de corte. Arquivo Brasileiro de Medicina Veterinária e Zootecnia 60:1197-1204
Mendoza, A.; La Manna, A.; Crespi, D.; Crowe, M. A. and Cavestany, D. 2008. Whole sunflower seeds as a source of polyunsaturated fatty acids for grazing dairy cows: Effects on metabolic profiles and resumption of postpartum ovarian cyclicity. Livestock Science $1: 183-193$

Mertens, D. R. 2002. Gravimetric determination of amylase-treated neutral detergent fiber in feeds with refluxing in beakers or crucibles: collaborative study. Journal of AOAC 85:1217-1240.

Moura, E. S.; Silva, L. D. F.; Peixoto, E. L. T.; Bumbieris Junior, V. H.; Ribeiro, E. L. A. and Mizubuti, I. Y. 2015. Sunflower cake in diets for lambs: intake, digestibility, nitrogen balance and rumen parameters. Semina: Ciências Agrárias 3:2247-2258.

NRC - National Research Council. 2007. Nutrient requirements of small ruminants. National Academy Press, Washington, DC.

Oliveira, A. S.; Campos, J. M. S.; Oliveira, M. R. C.; Brito, A. F.; Valadares Filho, S. C.; Detmann, E.; Valadares, R. F. D.; Souza, S. M. and Machado, O. L. T. 2010. Nutrient digestibility, nitrogen metabolism and hepatic function of sheep fed diets containing solvent or expeller castor seed meal treated with calcium hydroxide. Animal Feed Science and Technology 1:15-28, 2010.

Oliveira, M. D. S.; Mota, D. A.; Barbosa, J. C.; Stein, M. and Borgonovi, F. 2007. Composição bromatológica e digestibilidade ruminal in vitro de concentrados contendo diferentes níveis de torta de girassol. Ciência Animal Brasileira 8:629-638.

Palmquist, D. L. and Mattos, W. R. S. 2006. Metabolismo de lipídeos. p.287-310. In: Nutrição de ruminantes. Berchielli, T. T.; Pires, A. V. and Oliveira, S. G., eds. FUNEP, Jaboticabal.

Piola Junior, W.; Ribeiro, E. L. A.; Mizubuti, I. Y.; Silva, L. D. F.; Sousa, C. L. and Paiva, F. H. P. 2009. Níveis de energia na alimentação de cordeiros em confinamento e composição regional e tecidual das carcaças. Revista Brasileira de Zootecnia 38:1797-1802.

Saliba, E. O. S.; Rodriguez, N. M. and Piló-Veloso, D. 2003. Utilization of purified lignin extracted from Eucalyptus grandis (PELI), used as an external marker in digestibility trials in various animal species. p.1-9. In: Proceedings of the 9th World Conference on Animal Production. UFRGS, Porto Alegre.

Senger, C. C. D.; Kozloski, G. V.; Sanchez, L. M. B.; Mesquita, F. R.; Alves, T. P. and Castagnino, D. S. 2008. Evaluation of autoclave procedures for fibre analysis in forage and concentrate feedstuffs. Animal Feed Science and Technology 146:169-174.

Silva Sobrinho, A. G.; Purchas, R. N. and Kadim, I. T. 2005. Musculosidade e composição da perna de ovinos de diferentes genótipos e idades de abate. Pesquisa Agropecuária Brasileira 11:1129-1134

Van Soest, P. J. 1994. Nutritional ecology of the ruminant. 2nd ed. Cornell University Press, Ithaca.

Van Soest, P. J. and Robertson, J. B. 1985. Analysis of forages and fibrous foods. Ithaca, Cornell University. 202p.

Weiss, W. P. 1999. Energy prediction equations for ruminant feeds. p.176-185. In: Proceedings of the 61th Cornell Nutrition Conference for Feed Manufacturers. Cornell University, Ithaca.

Zapata, J. F. F.; Seabra, L. M. A. J.; Nogueira, C. M.; Bezerra, L. C. and Beserra, F. J. 2001. Características de carcaça de pequenos ruminantes do Nordeste do Brasil. Ciência Animal 11:79-86. 